\title{
Socio-Cultural Dimensions of Dugu Music of the Waala People of the Upper West Region of Ghana
}

\author{
Samuel Komla Gene* Emmanuel Abatanie Chandi \\ Department of Social Science, Nusrat Jahan Ahmadiyya College of Education, Wa \\ P.O. Box 71, Wa, Ghana
}

\begin{abstract}
The article is a documentation of the authors' research into the Duori dugu music of the Waala people in the Wa municipality of Upper West Region of Ghana. It underscored the socio-cultural dimensions of the dugu genre and also touched on the contexts of performance and the use of instruments. Grounded on the theory of cultural context, the authors addressed the interplay between musical performance and the rich culture that portrayed the musical identity of the Wa people and the Waala in general. Data was gathered through interviews and participant observation. It was found that apart from its contextual performance at the in-laws' programmes, the $d u g u$ group also performs at Damba festival as well as other programmes that are connected to the members. The write-up concludes that $d u g u$ music gives the people of Wa a solid sense of cultural identity through instrumental organization and the contexts in which it is performed.
\end{abstract}

Keywords: Socio-cultural, Dugu, cultural context, In-laws, Damba festival, Wa

DOI: $10.7176 /$ RHSS/12-2-03

Publication date: January $31^{\text {st }} 2022$

\section{Introduction}

The indispensable nature of African traditional music to an Africa cannot be overemphasized. It is a common phenomenon that makes the people unique and one of the forces that unite them. From dawn to dusk music pervades every activity of the African and serves as a medium through which they express their sentiment, accompany work and the other activities. Africans are blessed with a variety of traditional dances and Ghana is no exception. In the southern part of Ghana otofo, gahu, zigi and kundum are some of the dances performed and in the northern section bamaya, takai, bina, anle and dugu are among the traditional ensembles. Dugu is one of the traditional dances performed by the people of Wa, in the Upper West region of Ghana. Dugu was agreed upon by the elders of the dance in consultation with the first leader ( $D u g u ~ N a a$ ) to be the name of the ensemble. The name dugu also depicts the sound produced by the two talking drums (tumpaani), the male and the female. The male produces " $d u$ " sound and the female sounds " $g u$ ".

According to Nabie, a member of the Duori dugu group said dugu is a recreational dance formed in Wa Fongu with loy (hourglass drum) when some of his forefathers migrated from Nalerigu the capital town of the North East Region of Ghana. Later, the talking drum music which was used to accompany the funeral, and other announcements for the community were added together with other instruments. The musical instruments of Loohi one of the dances performed by the people of Nalerigu were adopted for dugu since its inception but the performance practices of $d u g u$ are different from that of Loohi. By sharing Nketia's view on the "zone of cultural interaction", Mukuma (2010) reiterated that people who fall within the same geographical zone might adopt musical instruments or other cultural practices of other cultures permanently because of favourable conditions. Nalerigu and Wa are within the savanna belt hence the materials for the preparation of the instruments are the same and accessible for their construction. Some of the musical instruments of dugu are similar to that of Fontomfrom ensemble but both ensembles have differences in technique of rendition, dance steps, and performance practices. Akin to Agbadza costume for males is that of $d u g u$ dance and the body movement to the rhythmic pattern of the $d u g u$ ensemble.

The performance of $d u g u$ dance started to spread to other parts of the Upper West region when one of the founding members migrated to Kpongu a suburb of Wa and formed a group there. Later people from other parts of Wa such as Sokpayiri and Nayiri engaged the leaders to form the group in their communities. The dance is currently performed in towns like Charia and Dorimon and it has been rolled out in other districts in the region such as Tanina in Wa west district and Kaleo in the Nadowli Kaleo district.

\section{Review of Related Literature}

Socio-cultural practices are the bedrock of every society in Ghana. People use these practices as criteria to identify a group of people. Traditional music is incorporated into some of these socio-cultural practices. These types of music are accompanied by dance (Persaud, 2011). Amoah et al (2002) and Kquofi et al (2015) posit that traditional music is an embodiment of socio-cultural practices such as chieftaincy. Being the custodian of the land, the chief and elders in Ghanaian societies perform so many activities out of which music plays a vital role. In some instances, music is used during rituals to invoke the gods. Morley (2009) is of the view that the 
relationship between musical activities and rituals hinge on direct participation. The gods sometimes possess the participants of the rituals and reveal a pending calamity or good things that await a community. As it stands, dugu music features in the majority of the chieftaincy activities of the Waala traditional area.

Traditional festivals are performed in various parts of Ghana to depict the practices and beliefs of the people. They are either performed annually or bi-annually to perpetuate our culture and to bring the people together to deliberate on the development of the communities. In Ghana, music forms the core of every traditional festival. It is used to advertise the festival and also plays other roles as posited by Armah et al. (2020) that, music in traditional festivals is considered not only as an aesthetic expression but also an approach for people to demonstrate their sentiment. Bonye (2011) is also of the view that traditional festivals are purportedly performed to take care of and safeguard tradition through songs, drumming and dancing. During the celebration of Damba festival by the Waala people to eulogize the Wa Naa and to mark the birth of Prophet Mohammed, different indigenous ensemble groups perform to grace the occasion including $d u g u$ group.

Funeral, one of the life-cycle events is performed for a deceased member of a community to bid him/her farewell to the spiritual world. This event is accompanied by different types of music depending on the cultural orientation of the people and the position of the deceased when he/she was alive. According to Kquofi et al. (2015) Akpi ensemble is performed at the funeral of chiefs and other prominent personalities in Logba traditional area in the Volta region and Braimah (2018) as cited in Ndah et al (2021) also posited that Adowa music and dance is customarily the funeral ensemble of the Akan p.8. Initially, the notion behind the formation of the Dugu ensemble is to be performed at the funeral of the in-laws of the male members of the group. These days the dance could be performed during the funeral of other members of the group except children. It is believed that children have not accomplished their mission on earth hence they will reincarnate, therefore their funerals are not accompanied by music and other activities such as that of the adults.

\section{Methodology}

The researchers conducted practical work in Wa town by getting to the performers of the dance. One of them got in the act as a member as posited by Driscoll (2011) that researcher might mingle with researched and become part. At the same time, the negative effects proposed by Kawulich (2005) about the participants were checked. A cordial relationship was developed between the researchers and the researched throughout the data collection process. Dugu Naa and other members of the group were interviewed followed by some members of the Wa Fongu community. This is in line with Creswell (2012) that "interview occurs when researchers ask one or more participants general, open-ended questions and record their answers" (p217). The interview was key in the work as it guided us to get first-hand information from the people who perform the dugu dance. As part of the fieldwork, the performance practices of the people were taken note of indirect observation to ascertain how $d u g u$ dance is performed as posited by Ciesielska (2018) that "active observing of events unfolding in front of our eyes to record behaviour in the environment where it naturally occurs" (p.44). The secondary sources were also resorted to in the course of getting to the participants.

\section{Discussion of Findings}

\subsection{Dugu Musical types and Instrumental Organization}

As part of a long-established custom, the $d u g u$ dance ensemble has two types of music. These are baaluu and sokodae

Baaluu

Baaluu is the dugu musical type that comes with a slow tempo due to the dance type that accompanies it. Nabie posited that the baaluu type is performed for the elderly in the group to dance to because the dance movement that accompanies it is less vigorous.

\section{Sokodae}

The sokodae comes with a fast tempo which requires a vigorous movement to accompany. It is therefore performed for the youth who have the energy and vitality to dance to and display their physical prowess. There is the concluding part of the sokodae which is known as kauri. This part of the style serves as a coda and prepares both the dancers and the instrumentalists to prepare and end the performance.

\subsection{Instrumentation}

There are seven musical instruments for $d u g u$ dance namely: lato (double bell), cela (horns), gangabile (small drum), loy (hourglass drum), tumpaani (talking drum) and pintin 


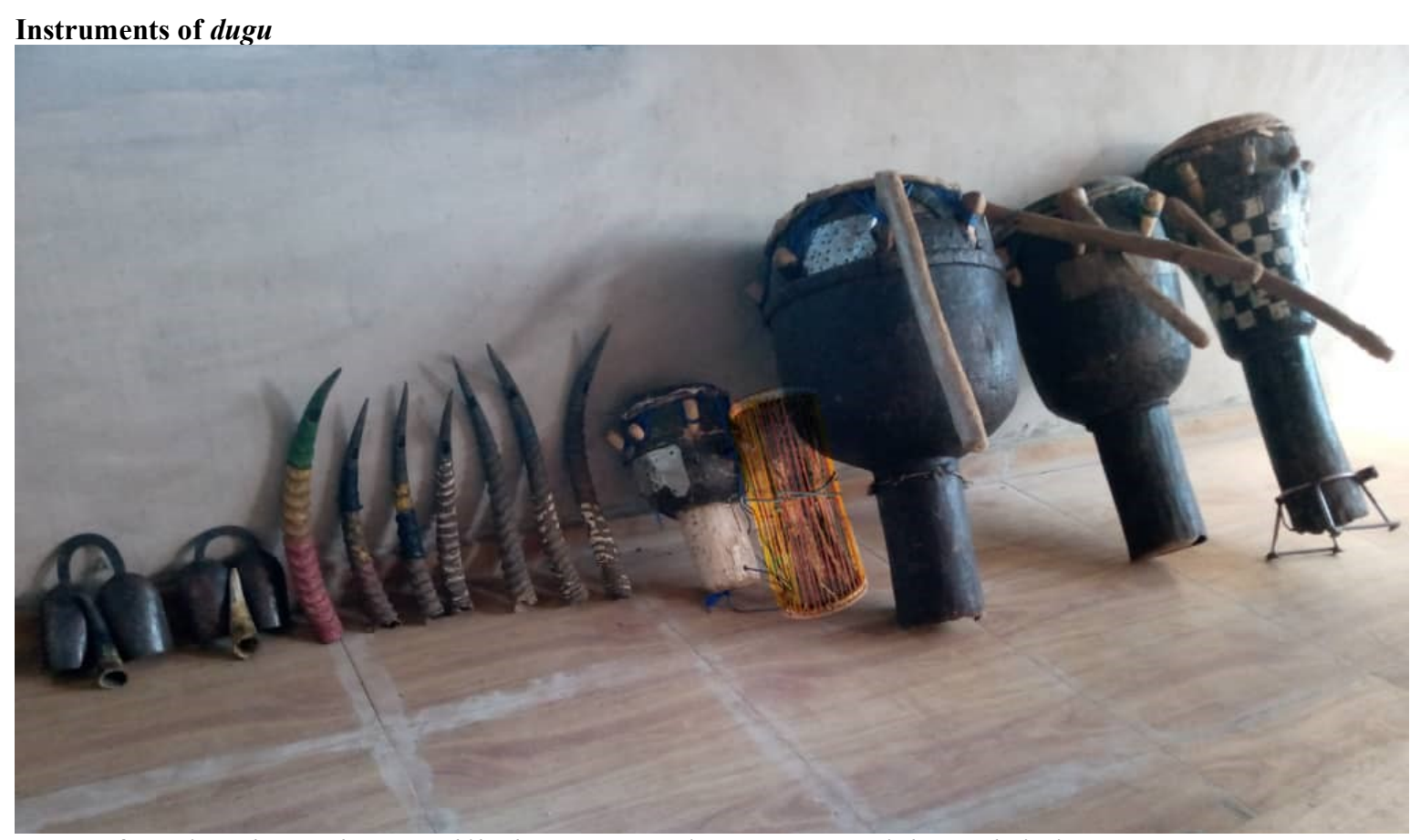

From left behind: lato, eela, gangabile, loys, tumpaani poga, tumpaani dao and pintin

\section{Description of the instruments}

The lato (double bell) are two metallic idiophones that control the rhythmic pattern of the dugu ensemble. They play the lead role in the ensemble as both start the performance and signal other instruments. The two are played with bull horns (cela).

The Eela (horns) are seven in number. They are the horns of gazelles acquired from the hunters in the Upper West Region of Ghana. Two are for calling and they are called Kpaahii (one is Kpaaha). The four that are for the response are known as Dechii (one is Dechaa). The seventh one is for both call and response and it is named Namu.

The rest of the instruments are drums with wooden resonators covered with either goat skin or calfskin parchment at one or both ends stretched to cover the surface with the support of heavy thread and pegs. The bigger the resonator the deeper the sound and the smaller the resonator the higher the sound. Aside from the loy, the rest of the drums are goblet in shape.

The smallest of the drums with a single head is the gangabile. It is an instrument with the highest pitch and also the one that is heard after the lato in the performance and it is played with two straight sticks. The next is the loy $>$ which is the only double-headed drum among them. It also has a high pitch and it is played with a forkstick under the armpit. The fifth instrument is the tumpaani dao (male talking drum). This drum has a bigger resonator and therefore produces a sonorous sound. It is paired with the tumpaani poga (female talking drum) whose resonator is smaller and both are played with two fork-sticks. The two together form the master drum of the ensemble and the appellations, praises and variations are performed on them. Next to the tumpaani poga at the right-hand side is the pintin drum. This is played with both hands. The optional instrument for $d u g u$ ensemble is the praa (castanet). 


\subsection{Hierarchical Structure of Dugu Membership}

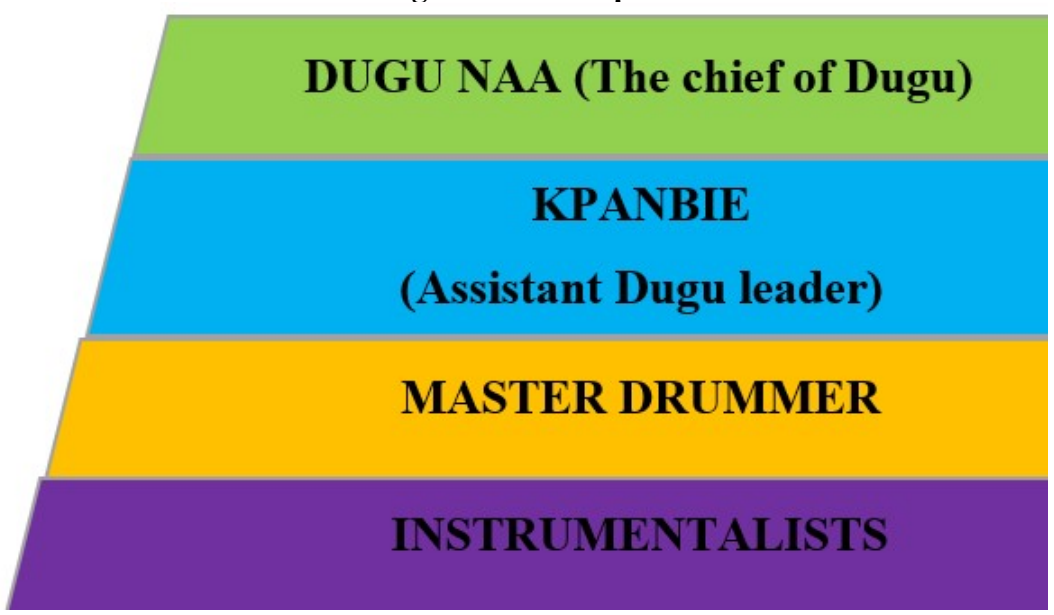

Fig. 1 Membership

The level of participation of individuals in the dugu group is diverse and this dwells on the ranking of the related significance of the performers. The diagram above depicts the hierarchical structure of the dugu membership. The first four positions of the group are sensitive and therefore occupied by men due to the patrilineality practiced by the Waalas. This assertion is in line with Sarkissian (1992) cited in Ebeli (2015) that "the issue of gender differences in musical roles as they operate in indigenous music operates in classical as well as popular music spheres" which is also related to the Waala tradition and practiced by dugu members.

At the peak of the dugu hierarchical structure is the Dugu Naa who is the mouthpiece of the group and also doubles as the highest authority representing the chief of the community in the dugu group. The next in command to the Dugu Naa is the Kpanbie (Assistant Dugu leader). He takes up the mantle of leadership of the group and stands in for the dugu Naa in his absence and accounts to him when he returns.

The master drummer's position is tactful due to the control he has over the other instrumentalists, the singers and dancers. The master drummer communicates with other performers in the group and also plays appellations to praise chiefs and other dignitaries during the performance. This position is so sensitive that ritual is performed to commit the occupant to the hands and care of the ancestors for protection.

The performance of the other instruments is also solely reserved for male members of the group. Concerning the male having the prerogative to the performance of the musical instruments, Sakata (1987), Sarkissian (1992) cited in Ebeli (2015) posited that "in Afghanistan musical instruments are generally played by men". This practice is common to the majority of both religious and secular music in Ghanaian communities and peculiar to the performance of music in educational institutions.

The dancers' and singers' roles might seem to be the last in the hierarchical structure but both positions are crucial and therefore essential to the ensemble. While the singers sing to accompany the drumming and dancing, the songs that they sing also contain the history and other issues that educate the audience about the Waala culture. The gestures and other movements made by dancers are based on the community life of the people of Wa.

\subsection{Formation}

On any stage or setting that the ensemble performs, the performers arrange in a horseshoe formation as follows. The drummers sit in front with the master drummer standing behind the talking drums (tumpaani). The horn blowers stand behind the drummers. At the extreme right and left sides of the drummers, the dancers stand at both ends facing each group at the opposite end and when it is time for them to dance, they come to the middle in front of the drummers. This formation creates a semi-circle for the dancers to have enough space to move about without impediment when dancing. Aside from the horseshoe formation, the dancers also sometimes organize themselves into files, circles, and ranks. Below is the illustration of the formation of instrumentalists. 


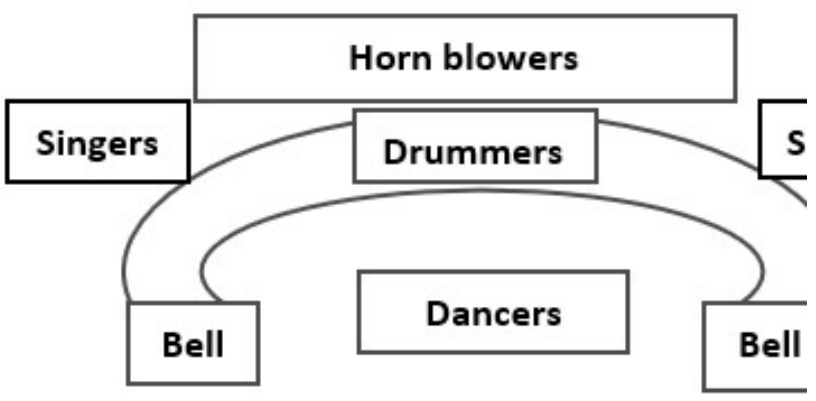

Fig. 2 Formation

\subsection{Admission of New Members}

Membership of $d u g u$ is made up of children (boys and girls above 12 years), men and women, Christians, Muslims, and Traditionalists. The acceptance of all manner of people in Wa and its environs as members of the $d u g u$ group consolidates the ideas of Gregory (1997) that music is a tool for uniting people and brings a sense of belonging. The above role of $d u g u$ music brings old and young together in a community performance thereby closing the generational gap and also people of different religious backgrounds converge and tolerate each other during the performance.

Apart from the children attaining certain age before becoming members, they are also supposed to be respectful, humble, and law-abiding. Those who show interest to be part of the group are trained to play various roles in the group such as singing dancing drumming and playing the horns. This is in line with Nketia (1988) who posited that enrolling performers is key to musical groups where various roles of the groups are assigned to pundits. In the $d u g u$ group, trainees are assessed and those whose performance in the assessment is exceptional are admitted into the group.

\subsection{Rituals Attached to the Ensemble}

Morley (2009) is of the view that "musical activities and religious, or spiritual, activities have much in common" (p.161). The two rituals that are attached to the $d u g u$ ensemble are the initiation of the master drummer and the one for the maintenance of musical instruments. According to Nabie, the master drummer is invited impromptu for the ritual and no time is fixed. The actual ritual and the process would not be disclosed because it is sacred and secret. If disclosed the detractors could get wind of it and find an antidote to it and charm the master drummer. For the maintenance of the musical instruments, a fowl is sacrificed to the gods for the quality sound and longevity of the instrument.

\subsection{Performance Contexts of Dugu Music}

Dugu was purposefully formed as the dance for the in-laws of men in the group. It is performed mainly during the funeral of either the fathers-in-law or mothers-in-law of the men to console the bereaved family and to entertain the sympathizers where sokodae and baaluu styles are performed. The songs to accompany both styles are carefully selected about the status of the deceased. The text of the songs is normally around appellations, folktales, proverbs, and sometimes insinuations depending on how family members took care of the dead during his or her last days. Okpewho (1992) classifies various African song texts about topics such as love, criticism, war, and death that throw light on oral literature as significant to social life and life cycle events. The $d u g u$ song texts at the funerals of the in-laws communicate the expertise of members of the group about life. Anyidoho (1992) is of the view that songs are powerful tools to proclaim critical views about current society by way of entertainment. The group played a pivotal role in preserving the oral literature of the traditional music of $d u g u$ appropriate to the current time in Ghanaian towns of Waala traditional area. 


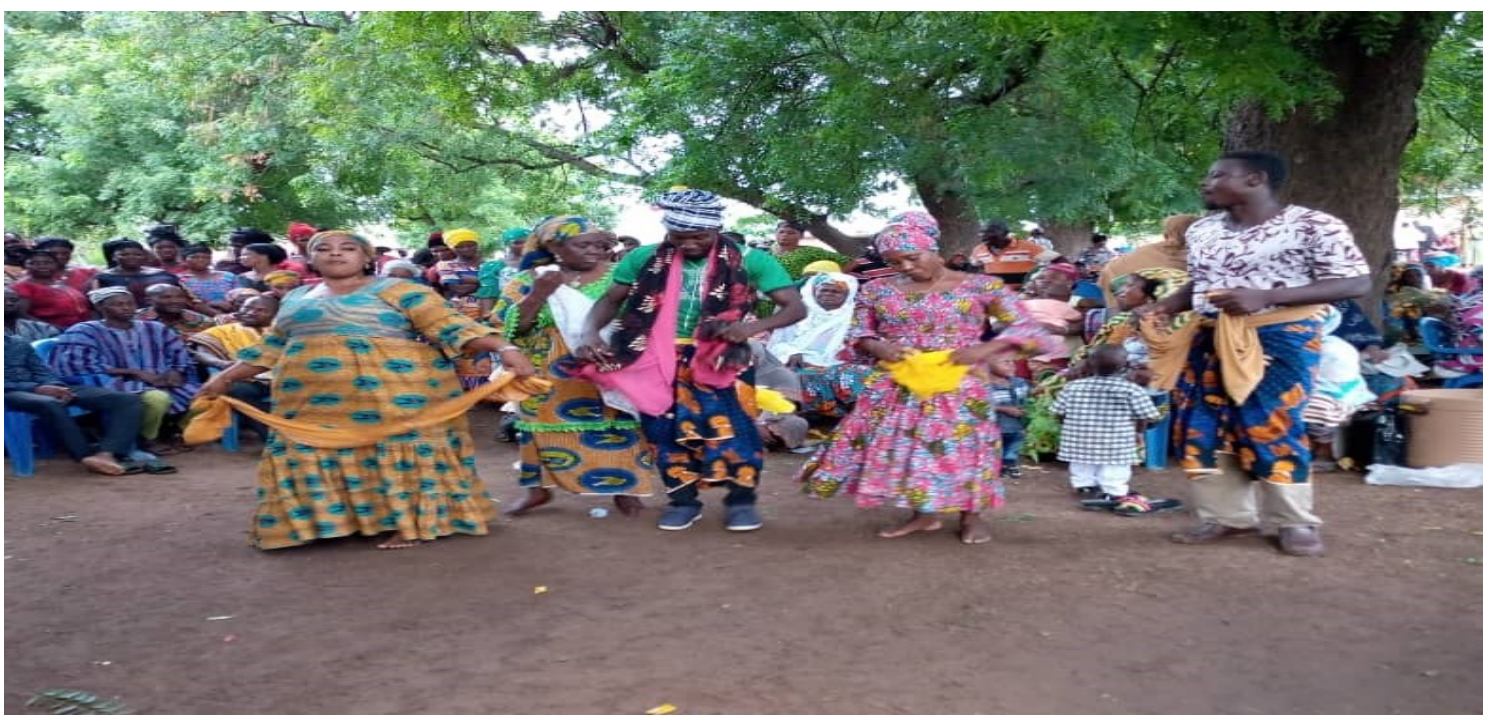

A performance at an in-law's birthday celebration

\subsection{Other Contexts}

Damba festival is among the occasions on which $d u g u$ ensemble is performed. Damba is the Mandingo language of the people of Sierra Leone which means a great dance. This was introduced during the reign of Naa Zangina (1648-1677) to Dagbon kingdom by Mandingo mallams which in due cause became a festival (Tia, 1969). This festival is performed every year in the month of Damba to mark the birth of the holy prophet Mohammed and also to laud the chief. This culture remained with the Waalas when they migrated from Nalerigu. Waala kingship is attached to the Islamic religion therefore the perpetuation and celebration of the festival every year by the people. Aside from the glorification of the chief and commemoration of the birth of Prophet Mohammed, a ritual is performed to climax the celebration where the chief jumps over a bull. This is done to check the chief's health condition and for the kingmakers to give him a nod to rule for another year. During the festival, dugu music is used to grace the occasion and also to praise the chiefs and the dignitaries with appellations.

Political rallies and other community functions are among the other events that dugu music features. The dance is performed to welcome the president and other political leaders to Waala communities as well as to perform at the programmes of the members of the group.

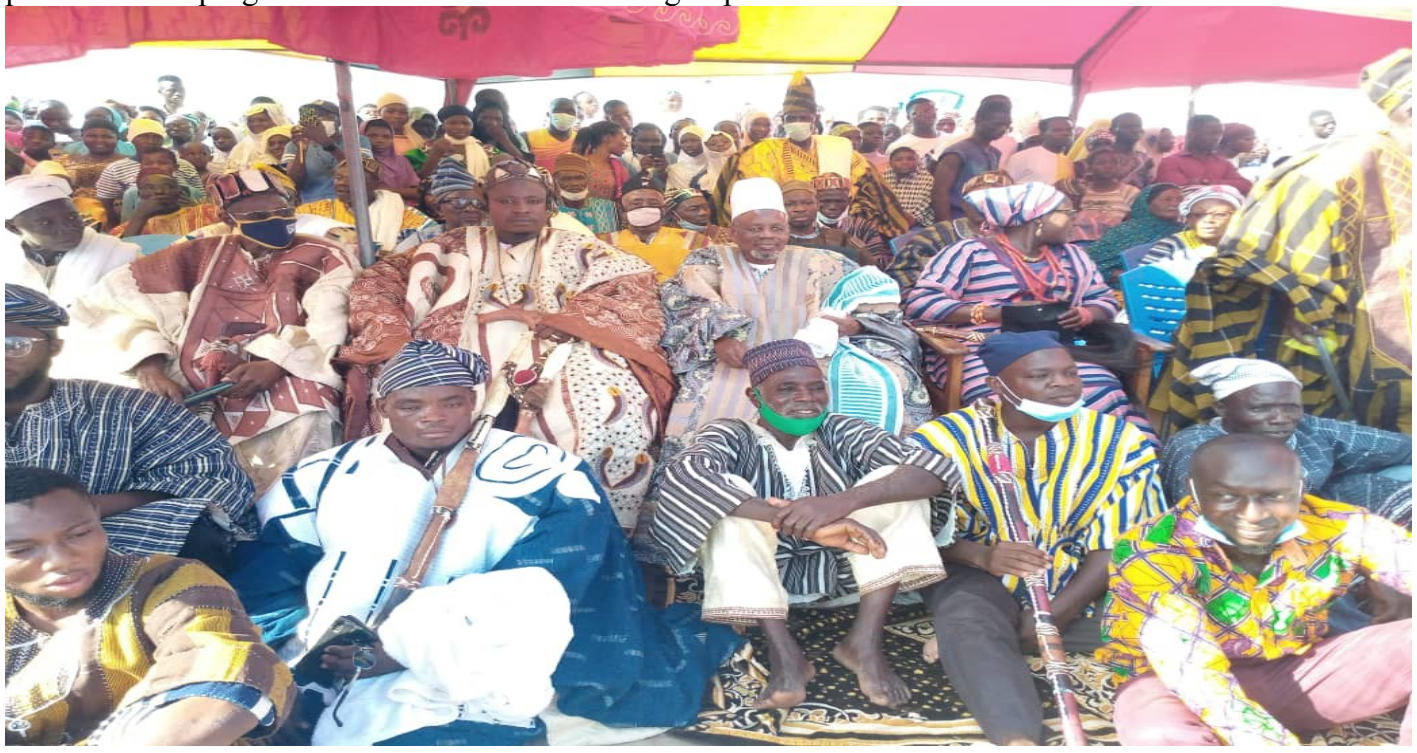

A durbar of chiefs in 2021 Damba Festival

\subsection{Performance Practice}

Due to effective supervision of the group by Dugu Naa and his assistant Kpanbie coupled with a regular rehearsal by the group, its performances are always superb. The two latos (double bells) start the performance 
for some time before the gangabile joins. Later, the pintin follows before the rest of the other instruments join in the performance.

This is followed by the dancers and singers. The dancers who dance in pairs thus a man to a woman and this could be in two, three, or four pairs at a time. As they move to the rhythm of the music, women grace the performance with ululation and also cheer up the dancers by putting a piece of cloth on the shoulders of the men around their necks. Both men and women move the hands and the legs to correspond with the movement of the torso as done in Agbadza dance. Men tie a piece of cloth around the waist on a pair of trousers and also put on a shirt or T-shirt. Women however put on a straight dress or slit and Kaba with a piece of cloth in their hands.

\subsection{Cultural Context of Dugu Musical Performance}

The essentiality of this discourse is within the perspective of cultural context, throwing light on the idea of musical performances in a cultural context. Dugu music plays a vital role in the lives of Waalas as an exclusive folk culture about other musical types such as Bina, Anle, Bawa, and Jassy because it is the main dance that features regularly at Damba festival and also a dance dedicated to the in-laws of Waala traditional area. The above information is about the two dugu musical styles performed during the Damba festival portraying the cultural identity of the Wa people and Waalas in general. In this context $d u g u$ music is seen as encompassing the culture of the people where their performances reflect their cognition, acting, and creating as posited by Merriam (1964) and cited in Wuaku (2015). The dugu repertory and performance practices are related to the cultural practices of the people of Waala traditional area through the performance of appellations by drummers, gestures by dancers, and the costumes worn by the performers that portray the rich culture of the Waalas in the Upper West Region of Ghana. Relating this to Impey and Nussbaum's (1996) discussion on “music and dance as tangible expressions of human values", that the arts become the avenue through which people utilize cultural resources to make social life meaningful in Africa. This calls for organizing the people, accommodating new changes, and reorganizing cultural assets to conform to changing trends of society.

\section{Conclusion}

The paper has ventured to demonstrate that dugu dance is active among the people of Wa like any custom of the Waalas. It is so because the Waala's understand the musical performance of the dugu genre in the contexts of inlaws and damba festivals to empower them to evoke and dramatize the cultural values that have been bequeathed to them across generations. The paper reveals that dugu musical types are two and both are performed in all contexts. It is imperative to note that the role of dugu music in the programmes of in-laws especially funerals and the damba festival cannot be underrated, as these two programmes cannot be performed without the ensemble. It is worth stating the role of the dance in perpetuating the cultural heritage of the people through drum beats, song texts and dramatic dances.

In conclusion, the heart of the programmes of in-laws and the damba festival is the dugu musical genre. The performances within these two contexts show the display of the cultural identity of the Waala people.

\section{REFERENCES}

Anyidoho, K. (1997). Ewe verbal art. In Francis Agbodeka (ed.). A Handbook of Ewe Land: Vol:1. The Ewes of Southern Ghana. Accra: Woeli Publishing Services, 23-52.

Armah, L., Darkoa, A. S., Ampomah, T. \& Osei-Sarfo, S. (2020). Performing art: A pivot of traditional festivals in Ghana. International journal of all research writings, 2(1), 94-103.

Bonye, S.Z. (2011). The role of traditional festivals in action planning, advocacy and social accountability. World J Young Researchers, 1(3), 32-39. http://www.rrpjournals.com/

Ciesielska, M., Bostrom, K.W. \& Ohlander, M. (2018). Observation methods. Retrieved on July 24, 2020, from https://doi.org/10.1007/978-3-319-65442-3_2

Driscoll, D.L. (2011). Introduction to primary research: Observations, surveys, and interviews. Writing Spaces, (2), 153-174.

Ebeli, E.A. (2015). Participation of women in the traditional music scene: Perspectives from Avatime Totoeme musical performance in Ghana. Global Journal of Arts, Humanities and Social Sciences, 3(12), 19-27.

Gregory, A.H. (1997). The roles of music in society: The ethnomusicological perspective. In D.J. Hargreaves \& A.C. North (Eds.), The social psychology of music (pp. 124-139). Oxford University Press.

Impey, A. \& Nussbaum, B. (1996). Sawubona Africa: Embracing four worlds in South African management. In Lessem, R. \& Nussbaum, B. (Eds.), Music and dance in Southern Africa: Positive forces in the workplace. Struik Publishers, Zebra Press.

Kquofi, S., Ndah, S. \& Tabi-Agyei, E. (2015). Serendipitous socio-cultural dynamics of Logba traditional musical ensembles in Ghana. European Journal of Research and Reflection in Arts and Humanities, 3(1), 13-25. www.idpublications.org

Kawulich, B. (2012). Doing social research: A global context. In C. Wagner, B. Kawulich \& M. Garner (Eds.), 
Collecting data through observation, (pp. 150-160). McGraw Hill.

Morley, I. (2009). Ritual and music - parallels and practice, and the Palaeolithic. In C. Renfrew \& I. Morley (Eds.), Becoming human Innovation in prehistoric material and spiritual cultures ( $1^{\text {st }}$ ed., pp. 159-175). Cambridge University Press.

Mukuma, K.W. (2010). The role of musical instruments in the globalization of music. Scientif Journal of Media Education, 83-88. DOI:10.3916/C34-2010-02-08

Nabie, R. (2021, July). Duori dugu. (S. Gene, Interviewer)

Nketia, J.H. (1988). The music of Africa. Victor Gonllancz Ltd.

Ndah, D.S., Ohene-Amoako, D., Issa, M., Kokro, F.K., \& Walden, P. (2021). Art and cultural elements in funeral rites of the people of Asante Mampong. Journal of Electronics and Communication Engineering Research, 7(4), 6-15. www.questjournals.org

Okpewho, I. (1992). African oral literature: Backgrounds, character, and continuity. Bloomington: Indiana University Press.

Persaud, D. (2011). Traditional Ghanaian Dance and its Roles in Transcending Western Notions of Community. Retrieved on 7th October 2013 from http:// scholar oxy.edu/rrap_student.

Tia, S. (1969). Dagbang Kaya ni Wahi. Accra: Bureau of Ghana Languages.

Wuaku, H.M. (2015). A contextual study of brass band music within the Peki-Kpando area of the Volta Region of Ghana. Unpublished PhD. Dissertation, University of Ghana. 